\title{
Penggunaan ZnO/Zeolit Sebagai Katalis Dalam Degradasi Tartrazin Secara Ozonolisis
}

\author{
Zilfa $^{1}$, Safni ${ }^{1}$, Febi Rahmi ${ }^{1}$ \\ ${ }^{1}$ Laboratorium Kimia Terapan Jurusan Kimia, Fakultas Matematika dan Ilmu Pengetahuan Alam, \\ Universitas Andalas, Padang, Sumatra Barat, Indonesia
}

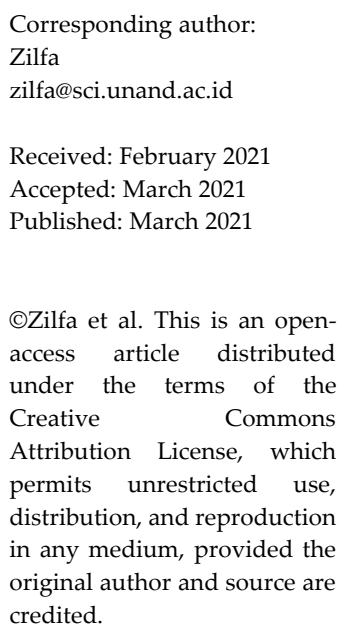

(C)Zilfa et al. This is an openaccess article distributed under the terms of the Creative Commons Attribution License, which permits unrestricted use, distribution, and reproduction in any medium, provided the original author and source are credited.

\begin{abstract}
An investigation on modification of natural zeolite with $\mathrm{ZnO}$ for the degradation of tartrazine. In this study, $\mathrm{ZnO}$ as a semiconductor is modified into a natural zeolite as support to form $\mathrm{ZnO} /$ zeolite that can increase the efficiency degradation of tartrazine. Further, the formed catalyst was added to tartrazine by determining the variation in ozonolysis time, the amount of addition of the catalyst, and the addition of a catalyst time. The results of degradation were determined by UV-Vis spectrophotometer at $424 \mathrm{~nm}$. The result showed that the percentage of degradation obtained on each catalyst in the degradation. The resulted percent degradation of $20 \mathrm{ml}$ of tartrazine at concentration of $15 \mathrm{mg} / \mathrm{L}$ using $20 \mathrm{mg} \mathrm{ZnO/zeolite} \mathrm{was} \mathrm{56.80 \% ,} \mathrm{while} \mathrm{using}$ $0.77 \mathrm{mg} \mathrm{ZnO}$ was $42.25 \%$, and with the addition of $19.23 \mathrm{mg}$ of Zeolite was $31.18 \%$, all of that condition was proceeded by 40 minutes of ozonolysis. Thus, the result indicates that the $\mathrm{ZnO} /$ zeolite catalyst can increase percentages of tartrazine degradation by ozonolysis. It is known that the catalyst $\mathrm{ZnO}$ /zeolite is very effective in increasing the degradation of tartrazine. Analysis of tartrazine compounds using fourier-transform infrared spectroscopy (FTIR) after degradation changes in wavenumber indicates that there is a breaking of the bonds of tartrazine compounds. Characterization of $\mathrm{ZnO}$ /zeolite catalyst using FTIR, X-Ray diffraction (XRD) and scanning electron microscope (SEM), in each spectrum there was no shift, indicating that there is no change in $\mathrm{ZnO} /$ zeolite structure.
\end{abstract}

Keywords: degradation, ozonolysis, $\mathrm{ZnO}$ /zeolite

\section{Pendahuluan}

$\mathrm{ZnO}$ adalah senyawa yang telah dikenal cocok digunakan sebagai katalis karena bersifat semikonduktor innert, memiliki band gap yang kecil, kekuatan oksidasi yang besar, tidak beracun, dan relatif murah ${ }^{[1]}$. Karakteristik $\mathrm{ZnO}$ sebagai katalis sangat tergantung pada ukuran partikel dan metode penyiapannya. Semakin besar luas permukaan per satuan masa katalis maka efektifitas katalis semakin baik ${ }^{[2]}$. Untuk memperluas ukuran partikel $\mathrm{ZnO}$ ini dapat disupport dengan material lainnya. Dalam pemanfaatan $\mathrm{ZnO}$ sebagai katalis sering di support dengan bahan material seperti zeolit ( $\mathrm{ZnO} /$ zeolit). $\mathrm{ZnO}$ sering digunakan untuk reaksi reaksi senyawa dalam pembetukan dan penguraian. $\mathrm{ZnO}$ telah banyak digunakan sebagai bahan katalis untuk penguraian senyawa baik organik maupun anorganik. Adapun untuk penguraian senyawa telah dilakukan dengan metoda degradasi. Metoda degradasi yang dilakukan adalah sonolisis, fotolisis dan ozonolisis. Hasil degradasi 
senyawa organik adalah $\mathrm{H}_{2} \mathrm{O}$ dan $\mathrm{CO}_{2}\left[{ }^{[3],[4]}\right.$. Beberapa penelitian telah dilakukan untuk meningkatkan hasil degradasi $\mathrm{ZnO}$ disupport dengan material zeolit $\left(\mathrm{ZnO} /\right.$ zeolit$^{[5]}$.

Zeolit adalah senyawa alumina silika yang memiliki ukuran pori tertentu. Selektivitas zeolit terhadap suatu reaksi disebabkan oleh ukuran pori zeolit yang hanya dapat dimasuki oleh molekul tertentu yang spesifik, yang disebut sebagai shape-selective catalysis. Berdasarkan sifatnya, zeolit telah banyak digunakan sebagai adsorben, penukar ion dan katalis termal serta sebagai pensuppot katalis. Salah satu jenis zeolit yaitu mordenit. Struktur mordenit merupakan struktur sangkar jenis Secondary Building Unit (SBU) 5-1 dengan dua saluran utama yaitu, saluran pertama yang dibatasi oleh 8 Oksigen (S-8R) dan saluran kedua yang dibatasi oleh 12 Oksigen (S-12R) yang ditunjukkan pada Gambar 1[3].

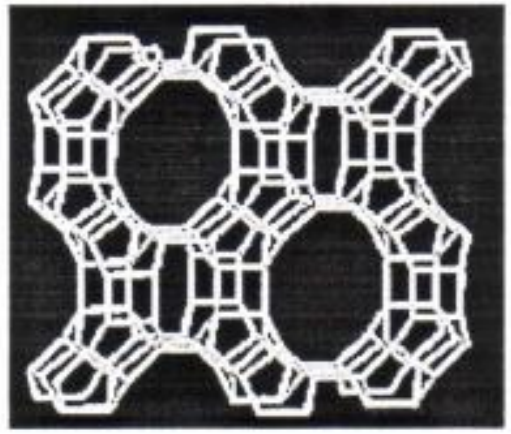

Gambar 1. Struktur mordenit zeolit ${ }^{[4]}$.

Katalis $\mathrm{ZnO} /$ zeolit telah banyak digunakan sebagai pendegradasi limbah-limbah organik seperti pestisida, obat dan zat warna. yang berbahaya sehingga menghasilkan senyawa $\mathrm{H}_{2} \mathrm{O}$ dan $\mathrm{CO}_{2}{ }^{[5]}$.

Semakin maraknya makanan dan minuman dijual, maka untuk menambah cita rasa makanan dan minuman konsumen menambahkan menyedap, sedangkan agar warna lebih menarik ditambakhkan zart pewarna. Adapun pewarna makanan berdasarkan sumbernya ada 2 macam yaitu pewarna alami dan pewarna sintetis. Pewarna alami harganya lebih mahal sedangkan pewarna sintestis lebih murah, sehingga orang cenderung menggunakan pewarna sintetis. Untuk pemakaian pewarna sintetis itu ada ambang batasnya kerena kelebihan memakan bahan pewarna sintetis akan menimbulkan bahaya bagi kesehatan tubuh[6]. Begitu juga bahan pewarna dari limbah pabrik juga akan memberikan dampak buruk bagi masyarakat kalau tidak diolah sebelum sampai kepemukiman, dimana air limbah itu nanti akan dimanfaatkan oleh masyarakat. Ambang batas penggunaan zat warna yang diperbolehkan adalah sekitar 220 ppm $^{[7]}$. Pemakaian zat warna untuk makanan dan minuman diatur dalam SK Menteri Kesehatan RI No.235/MenKes/Per/VI/79 dan direvisi melalui SK Menteri Kesehatan RI No.722/MenKes/Per/VI/88 mengenai bahan tambahan makanan.

Salah satu zat warna yang sering digunakan untuk pewarna makanan dan minuman adalah tartrazin. Tartrazin adalah salah satu zat warna sintesis yang digunakan dalam makanan, yang dikenal konsumen sebagai aditif. Limbah dari tartrazin sangat berbahaya yaitu bersifat racun terhadap pernafasan, iritasi terhadap kulit, dan dapat merusak hati serta ginjal. Kontaminan air limbah tartrazin ini tidak dapat terurai dengan cepat dan mudah ${ }^{[8],[9]}$.

Usaha yang telah dilakukan untuk mengatasi zat warna dalam limbah, antara lain: dengan adsorbsi[8],[10], koagulasi elektrokimia[11][12], degradasi elektrokimia menggunakan $\mathrm{C} / \mathrm{PbO}_{2}{ }^{[13]-[15]}$ dan elektrokoagulasinanofiltrasi ${ }^{[16]}$. Selain metoda tersebut dapat juga dilakukan dengan metode ozonolisis. Degradasi secara ozonolisis merupakan salah satu metoda degradasi senyawa organik dengan menggunakan ozon $\left(\mathrm{O}_{3}\right)$, dimana terjadi pemecahan ikatan antara $\mathrm{C}=\mathrm{C}$ sehingga menghasilkan ikatan rangkap $\mathrm{C}=\mathrm{O}$. Metoda ini merupakan kekuatan oksidasi oleh ozon untuk memutuskan ikatan rangkap pada senyawa organik. Hasil degradasi ini tergantung pada jenis ikatan rangkap yang teroksidasi dan kondisi kerja. Dalam fasa air, ozon dapat menguraikan $\mathrm{H}_{2} \mathrm{O}$ menjadi radikal $\mathrm{OH}$ atau 
basa konjugasi dari $\mathrm{H}_{2} \mathrm{O}_{2}\left(\mathrm{H}_{2} \mathrm{O}-\right)$ menjadi radikal $\mathrm{HO}_{2} \bullet$ dan $\bullet \mathrm{OH}^{[14]}$.

Untuk mendapatkan hasil dekomposisi yang efektif ditambahkan adsorben zeolit yang merupakan suatu kristal aluminosilikat yang memiliki pori-pori yang mengandung ion logam seperti $\mathrm{Na}^{+}, \mathrm{K}^{+}, \mathrm{Mg}^{2+}$, dan $\mathrm{Ca}^{2+}$, serta molekul air ${ }^{[17]}$ yang dapat mensupport katalis semikondukor $\mathrm{ZnO}$ yang memiliki energi celah atau band gap Eg yang sama $(3.2 \mathrm{eV})$ dan kestabilan yang sangat tinggi[18]. Prinsip dasar dari $\mathrm{ZnO} /$ zeolit adalah katalis $\mathrm{ZnO}$ akan masuk pada pori-pori zeolit yang telah diaktivasi sehingga akan menyebarkan katalis $\mathrm{ZnO}$ pada semua sisi zeolit dan menyebabkan permukaan $\mathrm{ZnO}$ semakin luas sehingga pembentukan hole semakin banyak. Banyaknya hole yang terbentuk akan diisi olek elektron yang akan menguraikan $\mathrm{H}_{2} \mathrm{O}$ menjadi $\mathrm{OH}$ radikal semakin banyak. Semakin banyak $\mathrm{OH}$ radikal maka persen degradasi semakin cepat dan banyak. Dengan pensupportan $\mathrm{ZnO}$ dengan zeolit disamping memperluas permukaan $\mathrm{ZnO}$, disini juga sekaligus terjadi simultan antara degradasi dan adosorbsi.

Dengan melakukan penelitian ini diharapkan dapat diketahui jumlah tartrazin yang terdegradasi secara ozonolisis dengan mempelajari beberapa pengaruh seperti waktu, dan jumlah penambahan katalis serta membandingkan hasil degradasi menggunakan $\mathrm{ZnO}$ saja, zeolit saja dan $\mathrm{ZnO} /$ zeolit.

\section{Metode Penelitian}

\section{Bahan kimia}

Bahan yang digunakan tartrazin (trisodium 5hydroxy 1-(4-sulfonatophenyl)-4-(4sulfonatophenylazo)-H-pyrazole-3 carboxylate), zeolit alam bayah jenis mordenit, akuades, zink oksida (ZnO)(Merk).

\section{Peralatan}

Alat yang digunakan adalah termometer, gelas piala, labu ukur, pipet tetes, batang pengaduk, corong, labu semprot, pompa hisap, klem, standar, pipet gondok dan kaca arloji, Spektrofotometer UV-Vis (S 1000 Secoman), ozone maker (Hanaco), neraca analitik, sentrifugator.

\section{Prosedur penelitian}

\section{Pembuatan katalis $\mathrm{ZnO} /$ zeolit}

Zeolit digerinda halus dan diayak dengan ayakan 320 mesh. Zeolit diaktivasi dengan $\mathrm{HCl}$. Kemudian diaduk menggunakan stirrer selama 45 menit lalu diukur $\mathrm{pH}$. Kemudian dibilas dengan air destilasi hingga $\mathrm{pH}$ netral. Setelah $\mathrm{pH}$ netral, zeolit disaring dan dioven selama 2 jam dengan suhu $100^{\circ} \mathrm{C}$.

\section{Penjenuhan zeolit}

Zeolit yang telah diaktivasi dijenuhkan dengan $\mathrm{NaCl} 0.01 \mathrm{M}$ lalu diaduk selama 1 jam. Kemudian zeolit dipisahkan dari filtrat dengan proses penyaringan, filtrat dari zeolit diuji dengan $\mathrm{AgNO}_{3}$ apabila masih terbentuk endapan putih maka zeolit dicuci dengan air destilasi hingga tidak terbentuk lagi endapan putih.

\section{Preparasi katalis $\mathrm{ZnO} /$ zeolit}

Zeolit yang telah dijenuhkan dimasukkan ke dalam air destilasi dan diaduk selama 6 jam, kemudian ditambahkan $\mathrm{ZnO}$ secara perlahan Kemudian dipisahkan dengan penyaringan vakum lalu dikeringkan dengan oven pada temperatur $100{ }^{\circ} \mathrm{C}$, lalu digerus sampai halus lalu diayak menggunakan pengayak 150 mesh. Hasil ayakan dikalsinasi pada temperatur $400{ }^{\circ} \mathrm{C}$ selama 10 jam.

\section{Proses degradasi}

Larutan tartrazin $1000 \mathrm{mg} / \mathrm{L}$ dibuat dengan menimbang sebanyak $0.05 \mathrm{~g}$ tartrazin, kemudian dimasukkan kedalam labu ukur 50 $\mathrm{mL}$ lalu dilarutkan dengan akuades sampai batas. Larutan induk tartrazin diencerkan menjadi $15 \mathrm{mg} / \mathrm{L}$. Larutan tartrazin $15 \mathrm{mg} / \mathrm{L}$ sebanyak $20 \mathrm{ml}$ masing masing dimasukkan kedalam 5 buah tabung kaca. Setelah itu dilakukan ozonolisis dengan variasi waktu dan penambahan katalis $\mathrm{ZnO} /$ zeolit. Pengaruh waktu dilakukan pada menit ke 10 hingga 50 menit. Selanjutnya dilanjutkan pada perlakuan 
dengan variasi jumlah katalis terhadap persen degradasi, dimana variasi jumlah katalis $\mathrm{ZnO}$ /zeolit 5, 10, 15, 20, $25 \mathrm{mg}$. Untuk memisahkan katalis $\mathrm{ZnO} /$ zeolit dari larutan hasil ozonolisis disentrifus selama 10 menit kemudian diambil filtratnya. Kemudian diukur absorban nya dengan spektrofotometer UV-Vis pada panjang gelombang $424 \mathrm{~nm}$. Hal yang sama dilakukan dengan menggunakan $\mathrm{ZnO}$ dan zeolit saja.

Hasil degradasi senyawa tartrazin di analisa dengan FTIR dan katalis $\mathrm{ZnO}$ /zeolit dikarakterisasi dengan FTIR, XRD dan SEM.

\section{Hasil dan Diskusi}

\section{Pengaruh waktu ozonolisis tanpa katalis} terhadap persen degradasi Tartrazin

Degradasi senyawa tartrazin secara ozonolisis tanpa katalis dilakukan dengan beberapa variasi waktu yaitu 10, 20, 30, 40, 50 menit. Persen degradasi ditentukan melalui persamaan (1).

$\% \mathrm{D}=\frac{\mathrm{A}_{0}-\mathrm{A}_{\mathrm{t}}}{\mathrm{A}_{0}} \times 100 \%$

Keterangan:

$\begin{array}{ll}\% \mathrm{D} & =\text { persen degradasi } \\ \mathrm{A} 0 & =\text { absorban awal } \\ \text { At } & =\text { absorban akhir }\end{array}$

Hasil degradasi dapat dilihat pada Gambar 2. Gambar 2 menunjukkan peningkatan persen degradasi pada waktu 40 menit didapatkan persentase degradasi sebesar $22.90 \%$.

Gambar 2 memperlihatkan bahwa semakin lama waktu ozonolisis, maka persen degradasi semakin meningkat, dimana pada waktu ozonisasi 40 menit, persen degradasi mencapai $22.90 \%$. sedangkan dengan waktu ozonisasi semakin meningkat, persen degradasi tidak meningkat. Hal ini disebabkan pembentukan radikar $\mathrm{OH}$ yang sudah berkurang. Peningkatan persen degradasi dikarenakan semakin lama kontak ozon dengan senyawa maka semakin banyak ikatan $\mathrm{C}=\mathrm{C}$ yang akan diputus pada larutan tartrazin. Ozon akan menguraikan $\mathrm{H}_{2} \mathrm{O}$ menjadi radikal $\mathrm{OH}$, yang nantinya radikal $\mathrm{OH}$ akan memutus $\mathrm{C}=\mathrm{C}$ menjadi $\mathrm{C}=\mathrm{O}$ dan gugusgugus fungsi lainnya. Semakin lama waktu ozonolisis pembentukan radikal $\mathrm{OH}$ semakin banyak sehingga pemutusan ikatan pada senyawa tartrazin semakin banyak yang mengakibatkan degradasi semakin tinggi dan persen degradasi semakin besar, namun suatu saat waktu semakin lama persen degradasi tidak berubah secara signifikan ini dikarenakan pembentukan radikal $\mathrm{OH}$ sudah konstan. Sehingga tidak terjadi pemutusan ikatan dari senyawa tartrazin.

\section{Pengaruh jumlah $\mathrm{ZnO/zeolit} \mathrm{terhadap} \mathrm{persen}$ degradasi tartrazin secara ozonolisis}

Untuk meningkatkan hasil degradasi dilakukan dengan penambahan katalis $\mathrm{ZnO} /$ zeolit.

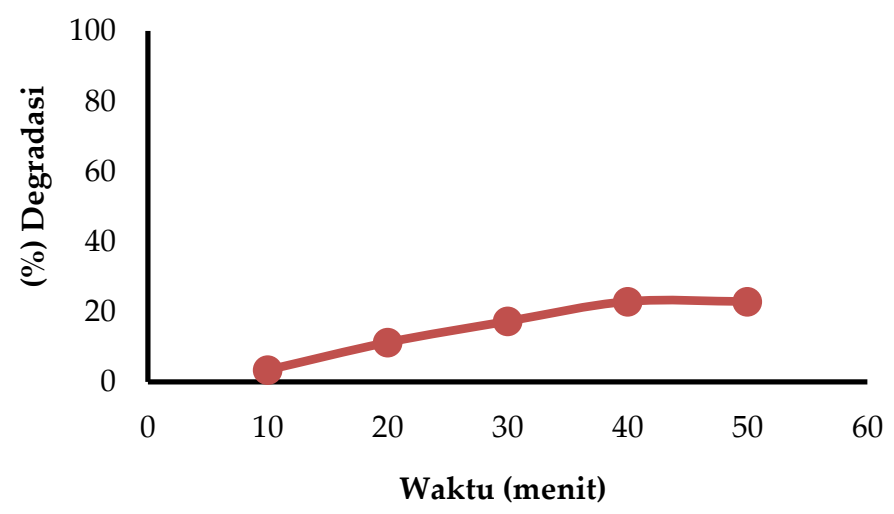

Gambar 2. Pengaruh waktu tanpa katalis terhadap persentasi degradasi Tartrazin secara ozonolisis. 
Adapun jumlah katalis yang digunakan adalah dengan variasi 5, 10, 15, 20, 25 mg. Hasil degradasi dapat dilihat pada Gambar 3. Gambar 3 memperlihatkan persen degradasi tartrazin setelah penambahan katalis $\mathrm{ZnO}$ /zeolit. Persen degradasi meningkat seiring penambahan jumlah katalis, dimana menggunakan katalis 20 mg yaitu sebesar $56.34 \%$ selama waktu 40 menit.

Penambahan katalis $\mathrm{ZnO} /$ zeolit sangat berpengaruh kepada tingkat degradasi, dimana semakin bertambah jumlah katalis, persen degradasi semakin bertambah. Hal ini disebabkan karena $\mathrm{ZnO} /$ zeolit berperan meningkatkan efisiensi degradasi tartrazin. Dengan adanya ozon, maka akan terjadi pemutusan ikatan antara $\mathrm{C}=\mathrm{C}$ pada alkena, menghasilkan ikatan $\mathrm{C}=\mathrm{O}$. Pengaruh penambahan $\mathrm{ZnO} /$ zeolit adalah untuk meningkatkan pembentukan radikal $\bullet \mathrm{OH}$. Ozon mengenai permukaan katalis sehingga terjadi eksitasi elektron dari pita valensi ke pita konduksi sehingga terbentuk hole, oleh karena media $\mathrm{H}_{2} \mathrm{O}$ maka electron hole akan menguraikan $\mathrm{H}_{2} \mathrm{O}$ menjadi $\mathrm{H}^{+}$dan $\bullet \mathrm{OH}$. Oleh sebab itu semakin besar jumlah katalis, pembentukan radikal $\mathrm{OH}$ semakin banyak, semakin banyak radikal $\mathrm{OH}$ semakin besar terdegradasinya senyawa tartrazin. Akan tetapi pemakaian katalis terlalu banyak mengakibatkan terjadinya kejenuhan sehingga pemakaian katalis tidak efisien lagi. Hal ini menyebabkan penyaringan tidak sempurna yang mengakibatkan pengukuran absorban semakin besar, sehingga hasil degradasi mengalami penurunan.

Mekanisme ozonisasi:

$\mathrm{O}_{3}+\mathrm{hv} \rightarrow \bullet \mathrm{O}+\mathrm{O}_{2}$

$\mathrm{H}_{2} \mathrm{O}_{2}+\mathrm{hv} \rightarrow 2 \mathrm{OH} \bullet$

$\mathrm{O}_{2}(\mathrm{ads})+\mathrm{e}^{-} \rightarrow \bullet \mathrm{O}_{2}$

$\mathrm{H}_{2} \mathrm{O}_{2}(\mathrm{ads})+\mathrm{e}^{-} \rightarrow \mathrm{OH} \bullet+\mathrm{OH}^{-}$

Reaksi ozonisasi holes pada permukaan:

Polutan $($ ads $)+\mathrm{h}^{+} \rightarrow($ Polutan $)+($ ads $) \rightarrow$ COX NOX, SOX

\section{Pengaruh waktu ozonolisis terhadap degradasi tartrazin dengan penambahan $\mathrm{ZnO} /$ zeolit}

Pengaruh waktu degradasi setelah penambahan katalis dilakukan untuk mengetahui peningkatan persen degradasi dan pengaruh efisiensi waktu ozonolisis. Variasi waktu yang digunakan adalah 10, 20, 30, 40, 50 menit. Hasil degradasi dapat dilihat pada Gambar 4. Gambar 4 memperlihatkan bahwa dengan penambahan katalis $\mathrm{ZnO}$ /zeolit $20 \mathrm{mg}$ dengan variasi waktu terdapat peningkatan persen degradasi setelah penambahan katalis dimana setelah ditambahkan katalis didapatkan persen degradasi sebesar $56.80 \%$ selama 40 menit.

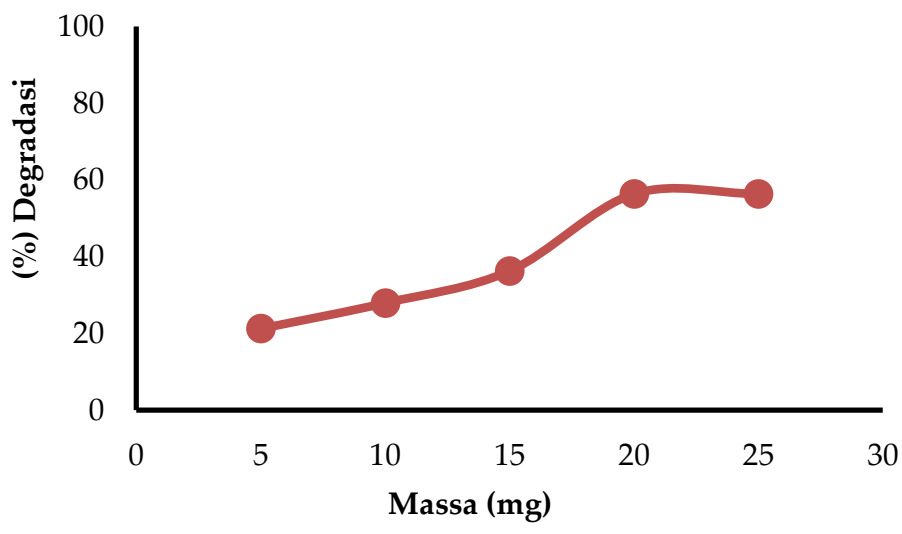

Gambar 3. Pengaruh masa $\mathrm{ZnO} /$ zeolit terhadap persen degradasi tartrazin secara ozonolisis. 


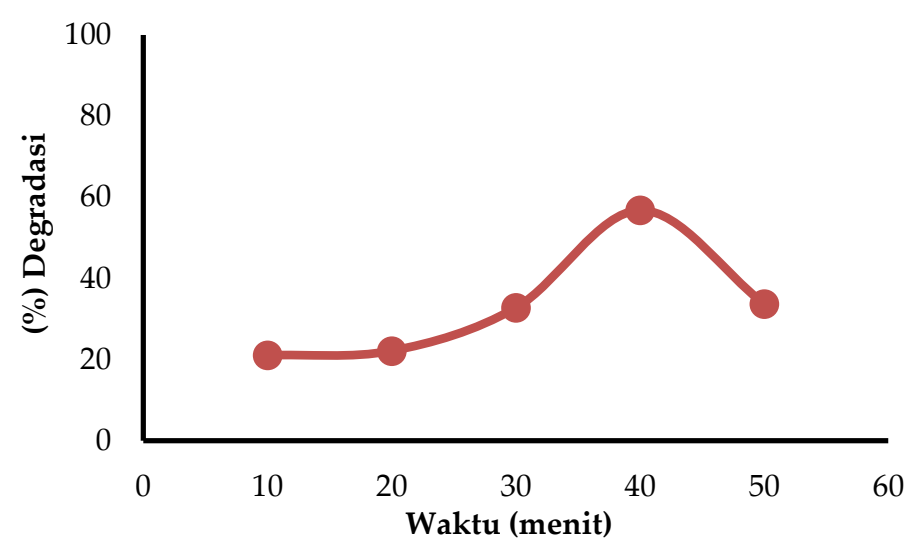

Gambar 4. Pengaruh waktu terhadap persen degradasi tartrazin secara ozonolisis setelah penambahan katalis $\mathrm{ZnO} /$ zeolit $20 \mathrm{mg}$.

Hal ini disebabkan karena $\mathrm{ZnO} /$ zeolit berperan meningkatkan efisiensi degradasi tartrazin. Dengan adanya ozon, maka akan terjadi pemutusan ikatan antara $\mathrm{C}=\mathrm{C}$ pada alkena, menghasilkan ikatan $\mathrm{C}=\mathrm{O}$. Dengan penambahan $\mathrm{ZnO} /$ zeolit akan dapat meningkatkan $\bullet \mathrm{OH}$ sehingga lebih banyak tartrazin yang didegradasi. Sementara semakin lama waktu, persen degradasi menurun, ini dikarenakan pengaruh radikal $\mathrm{OH}$ yang dihasilkan semakin lama akan terbentuk $\mathrm{H}_{2} \mathrm{O}_{2}$

Begitu juga dengan pemakaian alat ozon ini mempunyai daya keterbatasan waktu dalam pembentukan radikal $\mathrm{OH}$. Semakin lama waktu pemakaian ozon daya ozonisasinya berkurang mengakibatkan energi untuk mengeksitasi elektron dari pita valensi kepita konduksi semakin rendah sehingga pembentukan hole semakin sedikit. Dengan semakin sedikitnya hole mengakibatkan pembentukan radikal $\mathrm{OH}$ semakin menurun. Pada gambar 4 dapat dilihat yang mana tingkat persen degradasi terbesar adalah pada waktu 40 menit dengan persen degradasi mencapai $56.80 \%$.

\section{Pengaruh waktu ozonolisis terhadap degradasi tartrazin dengan penambahan $\mathrm{ZnO}$}

Pemakaian katalis $\mathrm{ZnO} /$ zeolit pada degradasi ini adalah $20 \mathrm{mg}$. Perbandingan pembentukan katalis $\mathrm{ZnO} /$ zeolit adalah 1:25 (ZnO:zeolit).

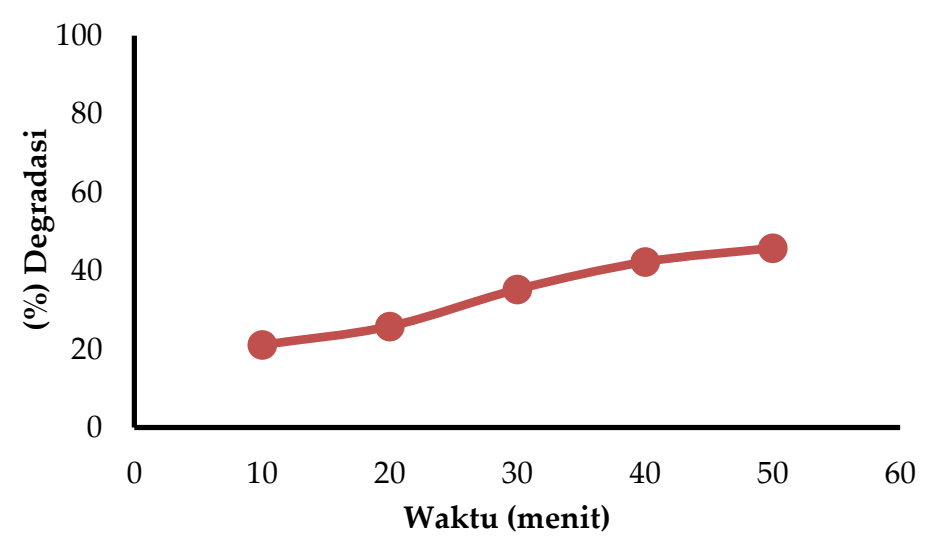

Gambar 5. Pengaruh waktu setelah ditambah katalis $\mathrm{ZnO} 0.77 \mathrm{mg}$ terhadap persen degradasi tartrazin secara ozonolisis. 
Pemakaian $20 \mathrm{mg} \mathrm{ZnO} /$ zeolit, menghasilkan komposisi $\mathrm{ZnO}$ adalah sebesar $0.77 \mathrm{mg}$ dan zeolit $19.23 \mathrm{mg}$. Hasil degradasi menggunakan $\mathrm{ZnO}$ saja dapat dilihat pada gambar 5. Gambar 5 menunjukkan bahwa persen degradasi menggunakan $\mathrm{ZnO}$ saja sebesar $42.25 \%$ selama 40 menit.

Hasil degradasi menunjukkan bahwa semakin lama waktu ozonisasi maka persen degradasi akan semakin besar, namun semakin lama waktu ozonolisis kenaikan persen degradasi tidak begitu signifikan disamping pembentukan $\mathrm{OH}$ radikal semakin sedikit kemampuan azonikator juga berkurang. $\mathrm{ZnO}$ adalah katalis semikonduktor yang mempunyai daya oksidasi tinggi. Penambahan $\mathrm{ZnO}$ disini adalah sebagai katalis. ZnO berperan meningkatkan efektifitas degradasi tartrazin, dimana dengan menggunakan ozon saja pembentukan radikal $\mathrm{OH}$ sangat sedikit sehingga kemampuan untuk menyerang gugus gugus yang ada pada senyawa tartrazin sedikit. $\mathrm{ZnO}$ akan meningkatkan jumlah radikal $\mathrm{OH}$, dimana radikal $\mathrm{OH}$ yang dihasilkan dari ozonolisis dapat meningkatkan kemampuan $\mathrm{ZnO}$ sebagai katalis untuk mempercepat dan memperbesar terjadinya degradasi. Dibandingkan hasil degradasi menggunakan $\mathrm{ZnO}$ dengan $\mathrm{ZnO}$ /zeolit, persen degradasi dengan $\mathrm{ZnO}$ /zeolit lebih besar ini disebabkan katalis $\mathrm{ZnO}$ /zeolit mempunyai luas permukaan yang besar, juga pada proses ozonolisis terjadi simultan antara degradasi dan adsorpsi. Disini $\mathrm{ZnO}$ sebagai pendegradasi dan zeolit sebagai adsorben.

\section{Pengaruh waktu ozonolisis terhadap degradasi tartrazin dengan penambahan zeolit}

Pengaruh penggunaan zeolit dapat dilihat dalam proses degradasi tartrazin. fungsi zeolit yang terbesar disini adalah untuk memperluas permukaan $\mathrm{ZnO}$ dan sebagai adsorben. Dalam hal ini dapat dilihat hasil degradasi menggunakan 19.23 mg zeolit pada Gambar 6 .

Pada Gambar 6 dapat dilihat bahwa pada menit 40 didapatkan persen degradasi yaitu $31.18 \%$ dengan penambahan zeolit. Persentase degradasi semakin meningkat seiring bertambahnya waktu, dimana semakin lama waktu ozonisasi pembentukan radika $\mathrm{OH}$ semakin banyak yang menyebabkan semakin banyak ikatan pada senyawa yang terdegradasi. Dengan adanya zeolit akan mempermudah radikal $\mathrm{OH}$ mencapai sasaran sehingga persen degradasi semakin besar dikarenakan kemampuan lain zeolit selain membantu memperluas permukaan zeolit juga berfungsi sebagai penyerap. Penurunan persen degradasi pada waktu ke 50 menit menunjukkan terjadi kejenuhan larutan sehingga sulit untuk dipisahkan yang mengakibatkan absorban menjadi besar sehingga konsentrasi menjadi kecil juga mengurangi efesiensi kemampuan ozon mendegradasi tartrazin.

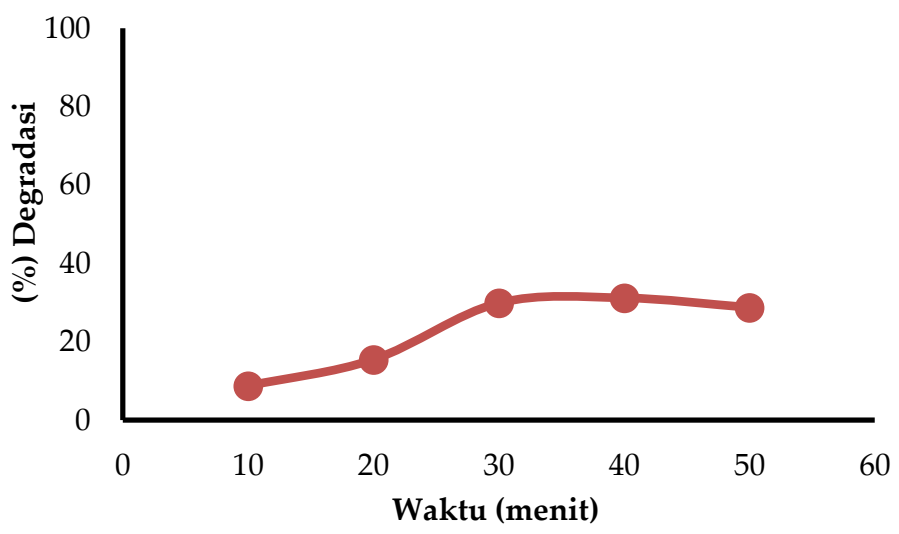

Gambar 6. Pengaruh waktu setelah ditambahkan zeolit $19.23 \mathrm{mg}$ terhadap persen degradasi tartrazin secara ozonolisis. 
Perbandingan persen degradasi dengan penambahan katalis $\mathrm{ZnO}$ /zeolit, $\mathrm{ZnO}$, dan zeolit

Gambar 7 menunjukkan persen degradasi pada Zeolit, $\mathrm{ZnO}$, dan $\mathrm{ZnO}$ /zeolit memiliki perbedaan sistematik masing-masing sebagai katalis dalam degradasi tartrazin.

Dimana pada zeolit yang memiliki persen terendah berada paling bawah pada kurva yang menunjukkan bahwa zeolit dalam jangka waktu tertentu efektifitas dalam degradasi semakin berkurang karena kejenuhan pada katalis tersebut, sementara dengan menggunakan katalis $\mathrm{ZnO}$ /zeolit pada kurva menunjukkan bahwa katalis ini memiliki efektifitas degradasi yang cukup baik namun pada waktu tertentu efektifitas menurun karena katalis mempercepat terbentuknya $\mathrm{H}_{2} \mathrm{O}_{2}$ sehingga mengurangi efesiensi $\mathrm{ZnO}$ /zeolit dalam degradasi, dan dengan katalis $\mathrm{ZnO}$ /zeolit dapat dilihat bahwa peningkatan yang signifikan menunjukkan bahwa katalis ini memiliki kemampuan degradasi yang lebih baik dari $\mathrm{ZnO}$ dan zeolit. Dari data dapat juga dilihat bahwa menggunakan $\mathrm{ZnO}$ saja persen degradasi meningkat seiring panambahan waktu. Setelah disupportnya $\mathrm{ZnO}$ dengan zeolit persen degradasi meningkat berarti zeolit telah dapat mengefektif dan efesiensi penggunaan $\mathrm{ZnO}$.

\section{Analisis tartrazin sebelum dan sesudah degradasi}

Tartrazin sebelum dan setelah degradasi dianalisa dengan menggunakan FTIR bertujuan untuk mengetahui tartrazin mengalami degradasi. Hasil analisis menggunakan FTIR dapat dilihat pada Gambar 8.

Gambar 8 menunjukkan spektrum FTIR dari larutan tartrazin sebelum degradasi dan setelah degradasi. Berdasarkan spektrum FTIR tersebut dapat dilihat pergeseran bilangan gelombang. Perubahan pita sterjadi pada bilangan gelombang 500-1000 $\mathrm{cm}^{-1}$ yang menyatakan pemutusan ikatan $\mathrm{C}-\mathrm{H}$ aromatik pada tartrazin dan pada bilangan gelombang $1600-2500 \mathrm{~cm}^{-1}$ terjadi sedikit pergeseran bilangan gelombang. Pada bilangan gelombang antara $3000-3500 \mathrm{~cm}^{-1}$ muncul pita serapan tandai vibrasi regangan $\mathrm{O}-$ $\mathrm{H}$ yang berasal dari molekul $\mathrm{H}_{2} \mathrm{O}$ sebagai pelarut. Disamping itu bilangan gelombang $1637.74 \mathrm{~cm}^{-1}$ adanya vibrasi regangan $\mathrm{C}-\mathrm{C}$ alifatik ${ }^{[19]}$.

\section{Karakterisasi katalis sebelum dan sesudah degradasi dengan FTIR}

$\mathrm{ZnO}$ /zeolit sebagai katalis degradasi tartrazin dikarakterisasi dengan FTIR dapat dilihat pada Gambar 9.

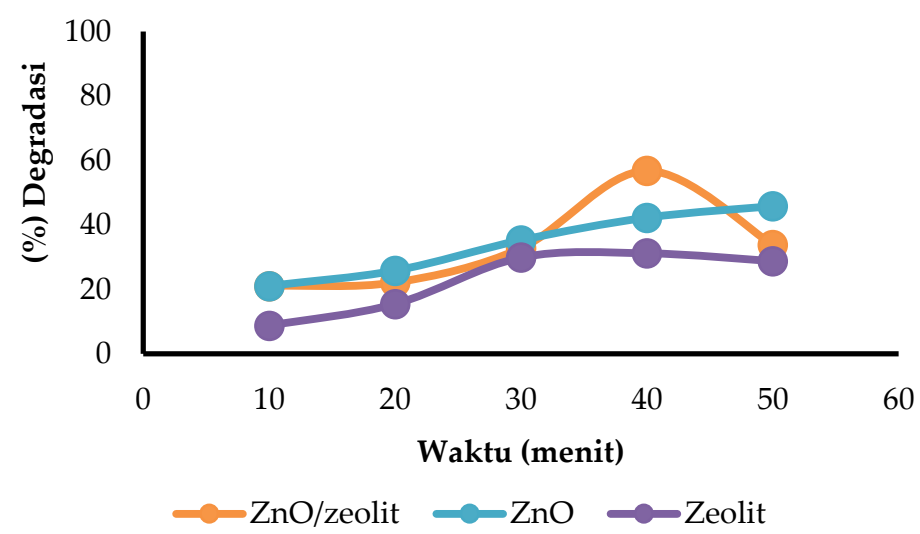

Gambar 7. Kurva perbandingan persen degradasi dengan penambahan katalis $\mathrm{ZnO} /$ zeolit, $\mathrm{ZnO}$ dan zeolit. 


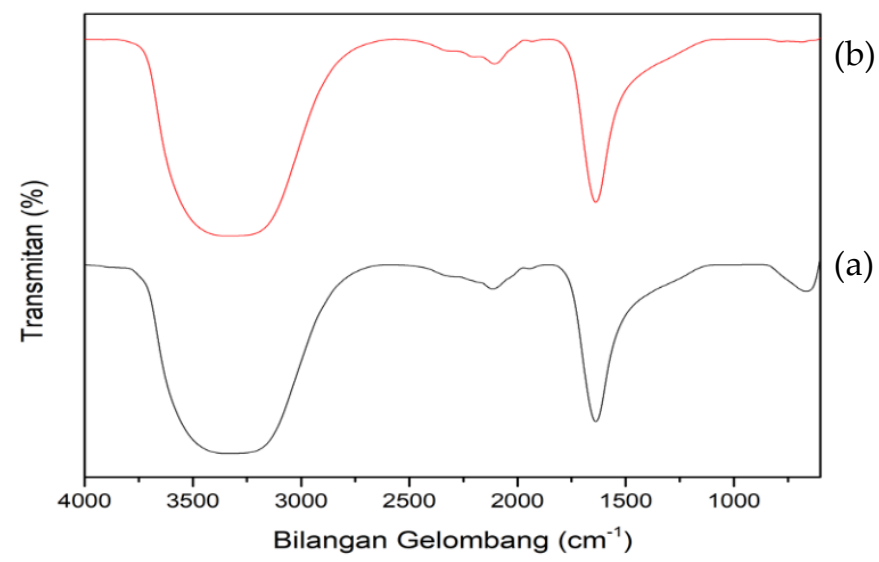

Gambar 8. Pola FTIR larutan tartrazin (a) sebelum degradasi, (b) setelah degradasi dengan penambahan katalis $\mathrm{ZnO} /$ zeolit.

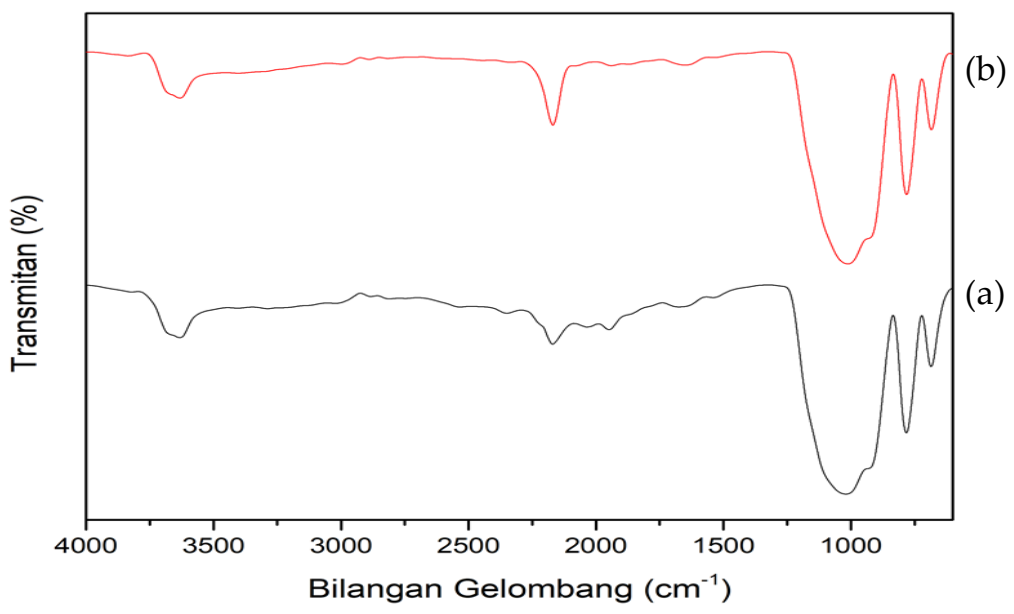

Gambar 9. Pola FTIR dari katalis $\mathrm{ZnO/zeolit} \mathrm{(a)} \mathrm{sebelum} \mathrm{degradasi,} \mathrm{(b)} \mathrm{setelah} \mathrm{degradasi.}$

Gambar 9 memperlihatkan pola FTIR dari katalis $\mathrm{ZnO} /$ zeolit sebelum dan setelah degradasi terdapat perubahan intensitas pada bilangan gelombang $1600-2500 \mathrm{~cm}^{-1}$ terjadinya pencucian katalis proses degradasi. Secara umum spektrum IR dari struktur zeolit berada pada kisaran 1500-3700 $\mathrm{cm}^{-1}$. Berdasarkan gambar diatas terdapat puncak pada bilangan gelombang 792.34 dan $1029.32 \mathrm{~cm}-1$. Bilangan gelombang tersebut mendekati nilai 790.34 dan $1049.16 \mathrm{~cm}^{-1}$ yang menandakan adanya ikatan TO-T, dimana $\mathrm{T}$ merupakan Si atau Al. Pita serapan $1694.39 \mathrm{~cm}^{-1}$ merupakan serapan dari ikatan $\mathrm{O}-\mathrm{H}$ yang berasal dari molekul $\mathrm{H}_{2} \mathrm{O}$, sedangkan pada bilangan gelombang 3532.33 $\mathrm{cm}^{-1}$ nilainya berkisar antara $3500-3750 \mathrm{~cm}^{-1}$ menujukkan vibrasi regangan dari $\mathrm{O}-\mathrm{H}$ yang berasal dari ikatan Al-O-Si. Ikatan antara Si$\mathrm{O}(\mathrm{Si})$ dan $\mathrm{Si}-\mathrm{O}(\mathrm{Al})$ berada pada kisaran 400-1200 $\mathrm{cm}^{-1}$. Secara umum pita serapan yang lemah antara 400-600 cm dan 463-1700 $\mathrm{cm}^{-1}$ menunjukkan regangan dari $\mathrm{ZnO}$ yang telah diamati untuk $\mathrm{ZnO}$ dalam berbagai komposit. Pada penelitian ini adanya $\mathrm{ZnO}$ diunjukkan oleh pita serapan pada bilangan gelombang 675.52

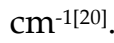




\section{Karakterisasi katalis sebelum dan sesudah degradasi dengan XRD}

Karakterisasi katalis $\mathrm{ZnO} /$ zeolit sebelum digunakan untuk degradasi dan setelah degradasi dilakukan dengan XRD seperti yang ditunjukkan Gambar 10.

Pada gambar diatas dapat dilihat pembentukan katalis $\mathrm{ZnO}$ /zeolit yang telah disupport oleh $\mathrm{ZnO}$. Berdasarkan gambar tersebut muncul puncak pada nilai $2 \theta$ yaitu pada $21.8^{\circ} ; 25.8^{\circ}$; $24.6^{\circ}$; dan $35.7^{\circ}$ yang menandakan puncak spesifik dari zeolit klinoptilolit dimana nilainya sesuai seperti yang ditunjukkan oleh data JCPDS no 39-138361 serta nilai $2 \theta$ tersebut juga memiliki kesamaan dengan nilai $2 \theta$ pada penelitian yang telah dilakukan Nezamzadeh, $\mathrm{dkk}, 2015$. Puncak yang yang muncul pada nilai $2 \theta 37.4^{\circ} ; 36.4^{\circ} ; 43.4^{\circ} ; 49.7^{\circ} ; 51.1^{\circ} ; 58^{\circ} ; 58.9^{\circ} ; 67^{\circ}$ menunjukkan bahwa adanya fasa kristal dari $\mathrm{ZnO}$, dimana data tersebut memiliki beberapa titik kesamaan nilai $2 \theta$ untuk $\mathrm{ZnO}$ pada daerah nilai $2 \theta 30^{\circ}$ dan $40^{\circ}$ sesuai dengan data JCPDS dari $\mathrm{ZnO}$ (JCPDS 36-1451) serta $\mathrm{ZnO}$ biasanya juga muncul pada nilai $2 \theta 48^{\circ}, 59^{\circ}, 62^{\circ}, 69^{\circ}$. Ini menunjukkan bahwa $\mathrm{ZnO}$ di support dengan zeolit selama proses kalsinasi berhasil dilakukan. Gambar 8 menunjukkan bahwa pola XRD katalis $\mathrm{ZnO} /$ zeolit sebelum degradasi dan setelah degradasi menyatakan tidak terjadi perubahan struktur terhadap katalis $\mathrm{ZnO}$ /zeolit selama proses degradasi.

\section{Karakterisasi katalis sebelum dan sesudah degradasi secara SEM}

Karakterisasi $\mathrm{ZnO}$ /zeolit sebelum dan setelah degradasi dilakukan dengan SEM untuk mengetahui morfologi dari katalis Gambar 11.

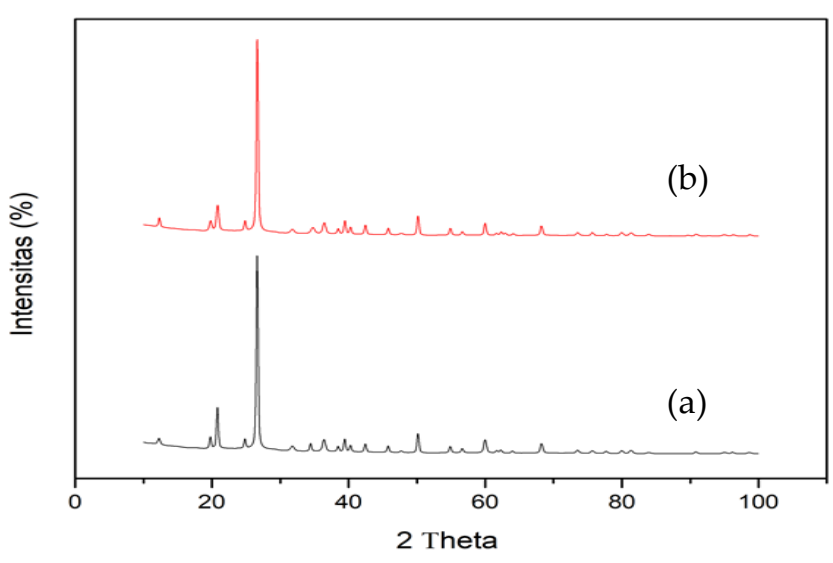

Gambar 10. Pola XRD dari katalis $\mathrm{ZnO/zeolit} \mathrm{(a)} \mathrm{sebelum} \mathrm{degradasi,} \mathrm{(b)} \mathrm{setelah} \mathrm{degradasi.}$
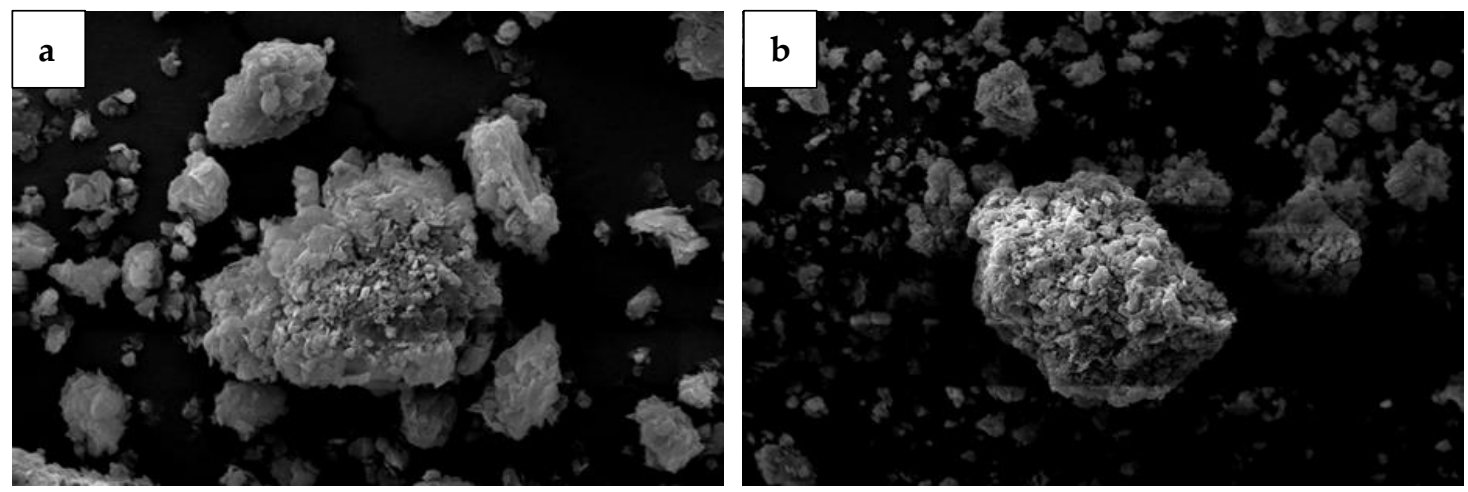

Gambar 11. Foto SEM dari katalis $\mathrm{ZnO}$ /zeolit (a) sebelum degradasi, (b) setelah degradasi. 
Gambar 11 menunjukkan morfologi pemukaan dari katalis $\mathrm{ZnO} /$ zeolit sebelum dan sesudah degradasi, dimana a dan $\mathrm{b}$ terdapat gumpalan dan material kecil pada permukaan gumpalan tersebut. Gumpalan tersebut diduga menunjukkan material zeolit, sedangkan material yang ada pada gambar b permukaan gumpalan diduga merupakan $\mathrm{ZnO}$. Berdasarkan foto SEM tersebut dapat dilihat bahwa tidak terjadi perubahan morfologi dari katalis $\mathrm{ZnO} /$ zeolit sebelum dan setelah degradasi.

\section{Kesimpulan}

Dari hasil penelitian dapat disimpulkan bahwa persen degradasi yang didapatkan pada masing-masing katalis dalam degradasi untuk pendegradasian $20 \mathrm{ml}$ tartrazin dengan konsentrasi $15 \mathrm{mg} / \mathrm{L}$ menggunakan $20 \mathrm{mg}$ $\mathrm{ZnO} /$ zeolit menghasilkan persen degradasi $56.80 \%$, sedangkan dengan menggunakan 0.77 mg $\mathrm{ZnO}$ menghasilkan $42.25 \%$, dan dengan penambahan $19.23 \mathrm{mg}$ Zeolit menghasilkan $31.18 \%$, semua dilakukan ozonolisis selama 40 menit. Hal ini menunjukkan bahwa katalis $\mathrm{ZnO}$ /zeolit dapat memperbesar persen degradasi tartrazin secara ozonolisis. Dengan demikian berarti bahwa zeolit dapat mengefektifkan pemakaian $\mathrm{ZnO}$. Analisis senyawa tartrazin dengan FTIR sesudah degradasi mengalami perubahan bilangan gelombang menandakan terjadinya pemutusan ikatan senyawa tartrazin. Karakterisasi katalis $\mathrm{ZnO}$ /zeolit dengan FTIR, XRD dan SEM, pada masing-masing spektrum tidak tampak terjadi pergeseran yang menandakan pola struktur $\mathrm{ZnO} /$ zeolit tidak mengalami perubahan.

\section{Ucapan Terima Kasih}

Terima kasih diucapkan kepada jurusan kimia FMIPA Universitas Andalas yang telah memfasilitasi penelitian ini dengan menyediakan kebutuhan penelitian. Terima kasih juga kepada analis laboratorium terapan yang telah membantu dalam pelaksanaan penelitin ini.

\section{Daftar Pustaka}

1. Omar, F. S., Nay Ming, H., Hafiz, S. M. \& Ngee, L. H., Microwave synthesis of zinc oxide/reduced graphene oxide hybrid for adsorption-photocatalysis application. Int. J. Photoenergy, 2014: 1-8 (2014).

2. Bunsho, O., Ogawa, Y. \& Nishimoto, S., Photocatalytic Activity of Amorphous Anatase Mixture of Titanium Oxide Particles Suspended in Aqueous Solutions. J. Phys. Chem., 101: 3726-3752 (1997).

3. Suarno., Degradasi Zat Warna Indogosol dengan Metode Oksidasi Katalitik Menggunakan Zeolit Alam Teraktivasi dan Ozononasi. Universitas Indonesia, (2010).

4. Suminta, S., Karakterisasi Zeolit Alam dengan Metoda Difraksi Sinar-X. J. Zeolit Indones., 5(2): 5-7 (2006).

5. Zilfa, Z., Rahmayeni, R., Septiani, U., Jamarun, N. \& Alif, M. F., Utilization Natural Zeolit From West Sumatera For TiO2 Support in Degradation of Congo Red and A Waste Simulation by Photolysis. Der Pharm. Lett., 9: 1-10 (2017).

6. Indrawatis, R., Tartrazina. http://.id.wikipedia.org/wiki/Tartrazina, 24/3/2021

7. Illing, I., Analisis Kandungan Zat Pewarna Tartrazin dalam Minuman Jajanan di Sekolah Dasar Kecamatan Wara Kota Palopo. J. Din., 2(1): 34-41 (2011).

8. Morales, G. V., Sham, E. L., Cornejo, R. \& Farfan, T. E. ., Kinetic Studies of The Photocatalitic Degradation of Tartrazine. J. Lat. Am. Appl. Res., 42: 45-49 (2012).

9. Al-dawery, S. K., Photo-catalyst Degradation of Tartrazine Compound in Wastewater Using $\mathrm{TiO} 2$ and UV Light. J. Eng. Sci. Technol., 8(6): 683-691 (2013).

10. Ghalwa, N. A., Abu-shawish, H. M., Tamous, H. M. \& Harazeen, H. Al., Determination of Electrochemical Degradation of E102 Dye at Lead DioxideDoped Carbon Electrodes Using Some Potentiometric and Spectrophotometric Methods. Chem. J., 3(1): 1-6 (2013). 
11. Schenone, A. V., Determination of tartrazine in beverage samples by stoppedflow analysis and three-way multivariate calibration of non- linear kineticspectrophotometric data. Elsevier Food Chem., 138(2-3): 1928-1935 (2013).

12. Amandeep, K. \& Usha, G., Simultaneous Determination of Binary Mixtures of Tartrazine and Quinoline Yellow Food Colorants in Various Food Samples and Cosmetic Products in Micellar Media by $\mathrm{H}-$ Point Standard Addition Method (HPSAM). Int. J. Res. Chem. Environ., 2(1): 293-300 (2012).

13. Zhang, J., Li, Y., Zhang, C. \& Jing, Y., Adsorption of malachite green from aqueous solution onto carbon prepared from Arundo donax root. J. Hazard. Mater., 150(3): 774-782 (2008).

14. Nidheesh, P. V., Gandhimathi, R., Ramesh, S. T. \& Singh, T. S. A., Adsorption and Desorption Characteristic of Crystal Violet in Bottom Ash Column. J. Urban Environ. Eng., 6(1): 18-29 (2012).

15. Esplugas, S., Giménez, J., Contreras, S., Pascual, E. \& Rodríguez, M., Comparison of different advanced oxidation processes for phenol degradation. Water Res., 36(4): 10341042 (2002).
16. Joseph, N. T. \& Chigozie, U. F., Efective Decolorization of Erichrome Black $T$, Furschin Basic and Malachite Green dyes from syntetic Wastewater by Electrocoagnanofiltration. Chem. Process Eng. Res., 21: 2224-7467 (2014).

17. Modirshahla, N., Abdoli, M., Behnajady, M. A. \& Vahid, B., Decolourization of Tartrazine from Aqueous Solutions by Coupling Electrocoagulation with $\mathrm{ZnO}$ Photocatalyst. Environ. Prot. Eng., 39(1): 5973 (2013).

18. Ghalib, A. M. \& AL-yaqoobi, A., Removal of Direct Blue Dye in Textile Wastewater Effluent by Electrocoagulation. J. Eng., 16(4): 6189-205 (2010).

19. Zuhriah, S., Degradasi Zat Warna Methyl Orange menggunakan Fotokatalis $\mathrm{ZnO} /$ Zeolit dengan Sinar UV. Universitas Brawijaya, (2011).

20. Bahrami, M. \& Nezamzadeh-ejhieh, A., Effect of the supported $\mathrm{ZnO}$ on clinoptilolite nano- particles in the photodecolorization of semi-real sample bromothymol blue aqueous solution. Materials Science in Semiconduktor Processing. 2015, 30, 275-284. Mater. Sci. Semiconduktor Process., 30: 275-284 (2015). 